\title{
PENGARUH PEKERJAAN KOKI DENGAN TERJADINYA DISFUNGSI EREKSI
}

\author{
${ }^{1}$ Marshella Bongkriwan \\ ${ }^{2}$ Benny Wantouw \\ ${ }^{2}$ Lusiana Satiawati
}

\author{
${ }^{1}$ Kandidat Skripsi Fakultas Kedokteran Universitas Sam Ratulangi Manado \\ ${ }^{2}$ Bagian Biologi dan Andrologi Fakultas Kedokteran Universitas Sam Ratulangi Manado
}

\begin{abstract}
Erectile dysfunction is a problem experienced by many men in the world. Spermatogenesis in the tubules seminiferi influenced by various factors for example, hormonal factors, inhibiting the function of epididymis, radiation and temperature. Spermatogenesis will be disrupted in the event of an increase in testicular temperature a few degrees of normal testicular temperature, that is $35^{\circ} \mathrm{C}$. The same effect can be found in daily activities when there is an increase in the heat of the environment such as a restaurant chef. This study is a descriptive study conducted in November 2013 to January 2014 with a sample size of 66 respondents. Interpretation of the 66 samples, obtained chef with normal erectile function by 7 people (10.6\%), mild dysfunction none, mild-moderate dysfunction as many as 40 people (60.6\%), moderate dysfunction 19 people (28.8\%), and no severe dysfunction. The conclution of this study found that the chef job can cause erectile dysfunction, prevalence of erectile dysfunction in a chef that $89.4 \%$ with mild-moderate and the longer the men exposed to high temperatures can cause persistent erectile dysfunction.
\end{abstract}

Keywords: chef jobs, erectile dysfunction.

\begin{abstract}
Abstrak: Disfungsi ereksi merupakan masalah yang dialami oleh banyak pria di dunia. Proses spermatogenesis didalam tubuli seminiferi dipengaruhi oleh berbagai faktor antara lain, faktor hormonal, penghambatan fungsi epididimis, radiasi dan faktor suhu. Spermatogenesis akan terganggu atau terhambat apabila terjadi peningkatan suhu testis beberapa derajat saja dari temperatur normal testis, yaitu $35^{\circ} \mathrm{C}$. Dampak yang sama dapat ditemukan pada rutinitas dan aktivitas sehari-hari ketika terjadi peningkatan panas dari lingkungan seperti koki restoran. Tujuan dari penelitian ini adalah untuk mengetahui apakah dapat terjadi disfungsi ereksi pada koki dan pengaruh pekerjaan koki terhadap terjadinya disfungsi ereksi. Penelitian ini adalah penelitian deskriptif yang dilakukan pada bulan November 2013 sampai Januari 2014 dengan besar sampel sebanyak 66 responden. Interpretasi dari 66 sampel, didapatkan koki dengan fungsi ereksi normal sebanyak 7 orang (10.6\%), disfungsi ringan tidak ada, disfungsi ringansedang sebanyak 40 orang (60.6\%), disfungsi sedang 19 orang (28.8\%), dan disfungsi berat tidak ada. Kesimpulan dari penelitian ini didapatkan bahwa pekerjaan koki memiliki pengaruh terhadap disfungsi ereksi, prevalensi disfungsi ereksi pada koki yaitu 89.4\% dengan derajat ringan-sedang hingga sedang dan semakin lama pria terpapar suhu tinggi terus-menerus dapat menyebabkan disfungsi ereksi.
\end{abstract}

Kata kumci: pekerjaan koki, disfungsi ereksi.

Masalah disfungsi ereksi merupakan masalah yang dialami oleh banyak pria di dunia. World health organization (WHO) memperkirakan, di Asia terdapat sekitar 87 juta pria yang menderita disfungsi ereksi.
Prefalensi disfungsi ereksi di Indonesia belum diketahui secara tepat, di perkirakan 16\% laki-laki usia 20-75 tahun mengalami disfungsi ereksi. ${ }^{1}$ 
Disfungsi ereksi atau impotensi didefinisikan sebagai ketidakmampuan yang konsisten untuk mendapatkan atau mempertahankan ereksi dalam memuaskan hubungan seksual. Batasan tersebut menunjukkan bahwa proses fungsi seksual laki-laki mempunyai dua komponen yaitu mencapai keadaan ereksi dan mempertahankannya. ${ }^{2}$

Peristiwa ereksi terjadi melalui gabungan kerjasama antara otak, susunan syaraf tepi, dan pembuluh darah di penis. Rangsang seksual diramu oleh otak kemudian diteruskan oleh sistem syaraf tepi sampai ke penis sehingga terjadi peningkatan aliran darah masuk ke penis serta tertutupnya aliran darah ke luar penis, sehingga penis menjadi memanjang, kaku dan keras. ${ }^{1}$

Ereksi terjadi sebagai efek hidrolik karena darah yang masuk dan yang dipertahankan dalam tubuh jaringan spons dalam penis. Proses ini paling sering dimulai sebagai hasil dari gairah seksual, ketika sinyal tersebut dikirimkan dari otak ke saraf di bagian panggul. ${ }^{3}$

Proses spermatogenesis didalam tubuli seminiferi dipengaruhi oleh berbagai faktor antara lain, faktor hormonal, faktor penghambatan fungsi epididimis, faktor radiasi, dan faktor suhu. Spermatogenesis akan terganggu atau terhambat apabila terjadi peningkatan suhu testis beberapa derajat saja dari temperatur normal testis, yaitu $35^{\circ} \mathrm{C}$. Dampak yang sama dapat ditemukan pada rutinitas dan aktivitas sehari-hari dimana terjadi peningkatan panas dari lingkungan seperti : pemakaian celana dalam yang ketat, koki restoran, mandi air panas (sauna), dan pekerjaan yang mengharuskan duduk lama selama berjamjam (misalnya sopir). ${ }^{4}$

\section{KERANGKA TEORITIS}

Penelitian ini berpijak pada suatu pemikiran dasar bahwa pria yang sering terpapar suhu tinggi lama dapat menyebabkan atrofi testis sehingga terjadi gangguan proses spermatogenesis dan terjadi defisiensi testosteron dan menyebabkan disfungsi ereksi.

\section{METODOLOGI PENELITIAN}

Penelitian ini merupakan penelitian deskriptif. Penelitian dilakukan di restoranrestoran chinese food yang ada di Manado pada periode November 2013 hingga Januari 2014. Populasi penelitian adalah seluruh koki yang ada di Manado. Sampel penelitian adalah seluruh koki chinese food di kota Manado yang memenuhi kriteria inklusi dan eksklusi. Tingkat ketepatan absolut yang dikehendaki adalah 5\% maka jumlah sampel yang didapatkan adalah 74 . Kriteria inklusinya adalah pria dengan pekerjaan koki yang sudah menikah usia 2555 tahun dan tidak memiliki penyakit kronik (misalnya diabetes melitus, jantung koroner dan hipertensi). Kriteria eksklusi adalah responden yang menolak dan responden yang memiliki riwayat penyakit kronik (misalnya diabetes melitus, jantung koroner dan hipertensi). Pada saat bertemu dengan koki restoran chinese food, perlu dijelaskan tujuan menjawab kuesioner. Dalam penelitian ini kuesioner yang digunakan adalah kuesioner IIEF (international index of erectile function) untuk menilai fungsi seksual pada pria. Perlu itanyakan juga adanya penyakit penyerta jika sesuai dengan kriteria inklusi maka responden dapat menandatangani lembar persetujuan. Lalu selanjutnya responden dapat mulai menjawab kuesioner yang diberikan.

\section{HASIL}

Selama jangka waktu penelitian mulai bulan November 2013 sampai Januari 2014, telah dilakukan penelitian terhadap 66 koki restoran chinese food. Selama penelitian ini terdapat 27 responden pada rentan usia 2030 tahun, 26 responden pada rentan usia 3140 tahun, 10 responden pada rentan usia 4150 tahun dan 3 responden pada rentan usia 51-60 tahun. Koki dengan fungsi ereksi normal sebanyak 7 orang (10.6\%), disfungsi ringan tidak ada, disfungsi ringan-sedang sebanyak 40 orang (60.6\%), disfungsi sedang 19 orang (28.8\%), dan disfungsi berat tidak ada. Hasil ini bisa mencerminkan bahwa ada pengaruh dari profesi koki dengan disfungsi ereksi karena dari 89.4\% 
(akumulasi disfungsi ringan-sedang dan sedang) koki yang diteliti mengalami disfungsi ereksi.

\section{BAHASAN}

Disfungsi ereksi adalah kegagalan dalam mengalami dan mempertahankan ereksi dengan rigiditas yang cukup untuk melakukan penetrasi. ${ }^{5} \quad$ Penyebab dari disfungsi ereksi merupakan gabungan dari banyak faktor seperti psikologis, neurologis, endokrin, vaskular, traumatic, dan komponen kimia. Menurut penelitian dari Seftel (2004) dikatakan sekitar 40\% penderita disfungsi ereksi mengalami hipertensi, hiperlipidemia, dan 20\% DM. ${ }^{6}$ Hal ini mungkin bisa ditemukan dalam penelitian ini jika sampel yang didapat lebih banyak. Dikatakan bahwa hipertensi, hiperlipidemia, DM, dan depresi merupakan faktor resiko terjadi disfungsi ereksi. ${ }^{6,7}$

Pada penelitian ini digunakan kuesioner IIEF, kuesioner IIEF sendiri terdiri dari 15 pertanyaan yang dapat mengukur fungsi ereksi (6 pertanyaan), fungsi orgasme (2 pertanyaan, hasrat seksual (2 pertanyaan), kepuasan hubungan kelamin (3 pertanyaan) dan kepuasan secara menyeluruh (2 pertanyaan). Yang digunakan dalam pertanyaan ini hanya 6 pertanyaan untuk mengukur fungsi ereksi sesuai dengan tujuan penelitian. ${ }^{8}$ Pertanyaan yang dipakai untuk mengukur fungsi ereksi yaitu, seberapa sering frekuensi ereksi dalam aktivitas seksual, frekuensi kekuatan ereksi saat penetrasi, frekuensi ereksi untuk penetrasi, frekuensi kemampuan untuk mempertahankan ereksi saat penetrasi, kesulitan mempertahankan ereksi untuk menyelesaikan hubungan seksual, dan tingkat keyakinan dalam mempertahankan ereksi saat penetrasi. Berdasarkan 6 pertanyaan tersebut kemudian dilakukan skoring dan kemudian hasilnya bisa dinterpretasikan.

Pengaruh dari profesi koki dengan disfungsi ereksi karena dari 89.4\% (akumulasi disfungsi ringan-sedang dan sedang) koki yang diteliti mengalami disfungsi ereksi. Ini menguatkan penemuan bahwa paparan panas dapat mempengaruhi testis sehingga akhirnya terjadi defisiensi testosteron yang mengakibatkan disfungsi ereksi. $^{9,10,11}$

\section{SIMPULAN}

Dari hasil penelitian ini dapat disimpulkan bahwa pekerjaan koki berpengaruh terhadap terjadinya disfungsi seksual. Prefalensi disfungsi ereksi pada koki yaitu 89,4\% dengan derajat ringansedang hingga sedang. Semakin lama pria terpapar suhu tinggi terus menerus dapat menyebabkan disfungsi ereksi.

Berdasarkan penelitian ini dapat disarankan bahwa perlu diadakan sosialisasi tentang pengaruh pekerjaan yang terpapar suhu tinggi terus-menerus dengan terjadinya disfungsi ereksi. Dianjurkan kepada koki pria untuk menggunakan handuk basah saat memasak dalam waktu lama di dekat kompor. Perlu diadakan penelitian lebih lanjut dengan jumlah responden dan waktu yang lebih banyak sehingga bisa didapatkan temuan baru.

\section{DAFTAR PUSTAKA}

1. Wibowo S, Gofir A. Disfungsi Ereksi. Yogyakarta: Pustaka Cendekia; 2007.

2. Bivalacqua TJ, Usta MF, Champion HC, Kadowitz PJ, Hellstrom WJG. Endothelial Dysfunction in Erectile Dysfunction: Role of the Endothelium in Erectile Physiology and Disease. Journal of Andrology. 2003; 24(S6).

3. Chew K, Earle C, Stuckey B, Jamrozik K, Keogh E. Erectile dysfunction in general medicine practice: prevalence and clinical correlates. International Journal of Impotence Research. 2000; 12(1): p. 41-45.

4. Ermiza. Universitas Kristen Maranatha. [Online].; 2012 [cited 2014 January 17. Available from: http://respiratory.maranatha.edu/2120/3/061 0113_chapter1.pdf.

5. NIH Consensus Conference. Impotence. NIH Consensus Development Panel on Impotence. JAMA 1993; 270: 83-90.

6. Seftel $A D$, Sun $P$, Swindle R. The Prevalence of Hypertension, Hyperlipidemia, Diabetes Mellitus And 
522 Jurnal e-Biomedik (eBM), Volume 2, Nomor 2, Juli 2014, hlm. 519-522

Depression In Men With Erectile Dysfunction. The Journal of Urology. 2004 June; 171(6): p. 2341-2345.

7. Demir T. Prevalence of erectile dysfunction in patients with metabolic syndrome. The International Journal of Urology. 2006 April; 13(4): p. 385-388.

8. Rosen R, Riley A, Wagner $\mathrm{G}$, et al. The International Index of Erectile Function (IIEF): A multidimensional scale for assessment of erectile dysfunction. Urology, 1997, 49: 822-830

9. Dada, R, NP Gupta and K Kucheria. Spermatogenic arrest in men with testicular hyperthermia.

Teratogenesis, Carcinogenesis, and Mutagenesis S1: 23543. 2003

10. Steinberger, A (1991) "Effects of temperature on the biochemistry of the testis.” In Zorgniotti (ed.) Temperature and Environmental Effects on the Testes. Plenum Press, NY.

11. Momen MN, Ananian FB, Fahmy IM, Mostafa T. Effects of high enviromental temperature on paramaters among fertile men. Fertility and Sterility. 2010;93(6):1884-6. 